\title{
STRATIFIKASI SOSIAL DALAM ISLAM: TINJAUAN TERHADAP STATUS SOSIAL DALAM KELUARGA DAN MASYARAKAT
}

\section{Syamsuriah Syamsuriah}

\author{
email: nasrunalboneh@yahoo.com
}

Dosen Fakultas Agama Islam Universitas Muslim Indonesia Makasar

\section{Abstract:}

What makes people differ from the others before Allah is just a religious piety (taqwa). In sociological perspective, Muslim people also talk about someone's social status, like the different status of the Prophet and the Messenger on the Earth, as well as status of khalifah and president as the ruler. So, stratification is known in Islam as the Qurān elucidated about the noble pious men on the Earth. The emergence of social stratification in society begins since the early existence of man, and it differs from one community to the other in different places, customs, traditions, and norms that are practiced in each community.

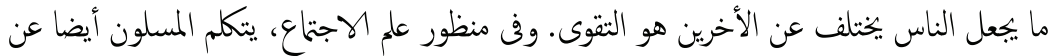

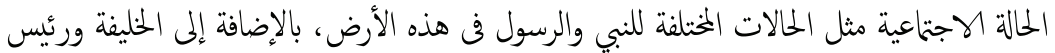

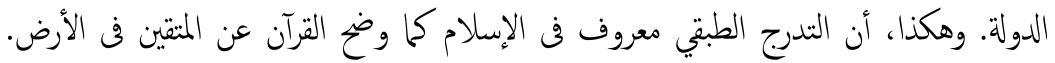

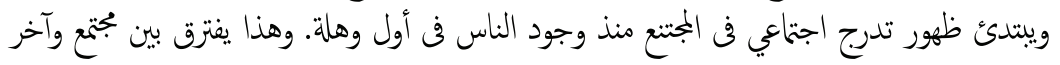

$$
\begin{aligned}
& \text { في مختلف الأمكنة والعوائد والمعايير في كل من المجتمعات. }
\end{aligned}
$$

Kata Kunci: Islam, stratifikasi sosial, masyarakat, keluarga

\section{Pendahuluan}

Keluarga adalah salah satu mata rantai kehidupan yang paling esensial dalam kehidupan manusia. Setiap manusia senantiasa merindukan dan mengharapkan hidup yang penuh kedamaian dan tentraman dalam kehidupan sosisialnya, hal ini sangat di dambakan setiap 
Syamsuriah Syamsuriah, STRATIFIKASI SOSIAL DALAM ISLAM: Tinjauan...

keluarga $^{1}$, masyarakat senantiasa mempunyai penghargaan tertentu dalam keluarga atau masyarakat yang bersangkutan. Penghargaan yang lebih tinggi atau lebih rendah terhadap hal-hal tertentu dalam nilai-nilai Iman, akan menempatkan hal tersebut pada kedudukan yang lebih tinggi dari hal-hal yang lainnya.

Secara sosiologi, didalam suatu keluarga, masyarakat lebih menghargai iman dan takwa ${ }^{2}$ dibandingkan kekayaan materia, maka dalam keluarga itu termasuk keluarga yang mulia, sebab didalam Alqurān sudah jelas di katakan pada Surah Al-Hujarāt (49) : $13,{ }^{3}$ Pada ayat ini dijelaskan bahwa orang yang paling mulia disisi Allah diantara kamu adalah orang yang paling bertaqwa. Hal itu dilihat dari segi ketaqwaannya tetapi jika dilihat seseorang dari segi materi dan kedudukan yang lebih tinggi dibandingkan dengan yang lain maka terjadilah gejala gejala masyarakat yang berlapis-lapis.

\section{Pembahasan}

\section{A. Stratifikasi sosial}

Bentuk - bentuk lapisan masyarakat berbeda-beda dan banyak sekali, lapisan-lapisan masyarakat tersebut masih tetap ada, sekalipun dalam masyarakat kapitalistis, demokratis, komunistis dan lain sebagainya. Lapisan masyarakat itu mulai ada sejak manusia mengenal adanya kehidupan bersama didalam suatu organisasi sosial, misalnya pada masyarakat yang bertarap kebudayaannya masih bersahaja. Lapisan masyarakat mula-mula didasarkan pada perbedaan, perbedaan antara pemimpin dengan pemimpin dengan yang dipimpin, golongan budak,

${ }^{1}$ Dr. Muhammad fasl-Ur-rahman Ansari, Konsep Masyarakat Islam Modern (Cet. I; Bandung: Risalah Bandung, 1983), h. 168

${ }^{2}$ H. Muhammad daud Ali. Pendidikan Agama Islam, Edisi I, Cet.II; Jakarta : PT. RajaGrafindo Persada, 1998), h. 369-370

${ }^{3}$ Kementerian Agama RI, Alqurān dan Terjemahnya, (Bandung: FokusMedia, 2010), h. 517 


\section{$\Delta L-n i s h \exists \bar{\Delta} h$,Vol. 11 No. 2, Juli-Desember 2015: 293-300}

pembagian kerja bahkan juga suatu pembedaan berdasarkan kekayaan. Semakin rumit dan semakin maju teknologi suatu masyarakat, semakin kompleks pula sistem lapisan masyarakat. Pada masyarakat kecil serta bersahaja biasanya perbedaan-perbedaan kedudukan dan peranan bersifat minim, karena warganya sedikit dan orang-orang yang dianggap tinggi kedudukannya juga tak banyak baik macam maupun jumlahnya. Dan didalam masyarakat yang sudah kompleks karena banyaknya orang dan aneka warna ukuran yang dapat diterapkan terhadapnya. ${ }^{4}$

Menurut Soerjono Soekanto, bentuk-bentuk kongkrit lapisan masyarakat tersebut banyak, akan tetapi secara prinsipil bentuk - bentuk tersebut dapat diklafikasikan kedalam tiga macam kelas yaitu yang ekonomis, politis dan yang didasarkan pada jabatan - jabatan tertentu dalam masyarakat. Umumnya ketiga bentuk pokok tadi mempunyai hubungan yang erat satu dengan yang lainnya, dimana terjadi saling pengaruh mempengaruhi.

\section{Terjadinya sistem lapisan masyarakat}

Adanya sistem lapisan masyarakat dapat terjadi dengan sendirinya dalam proses pertumbuhan masyarakat itu. Tetapi ada pula yang sengaja disusun untuk mengejar suatu tujuan bersama. Yang biasa menjadi alasan terbentuknya lapisan masyarakat yang terjadi dengan sendirinya adalah kepandaian, tingkat umur (yang senior), sifat keaslian keanggotaan kerabat seorang kepada masyarakat, dan mungkin juga kasta dalam batas - batas tertentu. Alasan-alasan yang dipakai berlainan bagi tiap-tiap masyarakat. Pada masyarakat yang hidupnya dari berburu hewan alasan utama adalah kepandaian berburu. Sedangkan pada masyarakat yang telah menetap dan bercocok tanam, maka kerabat pembuka tanah (yang dianggap asli) dianggap sebagai orang yang menduduki lapisan tinggi. ${ }^{5}$

${ }^{4}$ Soerjono Soekanto, Sosiologi Suatu pengantar, Edisi .IV, Cet. XXV; Jakarta : PT. RajaGrapindo Persada,1998), h. 252-253

5Ibid. h. 253-254 
Syamsuriah Syamsuriah, STRATIFIKASI SOSIAL DALAM ISLAM: Tinjauan...

Hal ini juga dilihat pada masyarakat Arab, seperti gerakan yang didirikan oleh Ahmad Syurkati lebih ditujukan pada imigran Arab dari Hadrami, ini dimana mereka dibagi dalam tiga kelas masyarakat. Yaitu :Pertama, orang - orang biasa dan kelas bawah di Hadramaut, termasuk pedagang kecil. Kedua, orang - orang terpelajar yang dengan bangga mendapat gelar syekh dan dianggap sebagai pemimpin agama. Dihadramaut para syekh ini menyukai posisi tinggi mereka. Ketiga, golongan Sayid yang menganggap dirinya keturunan langsung Nabi Muhammad Saw. Mereka berasal dari garis keturunan Basrah, Ahmad alMuhajir, yaitu cucu ketujuh dari cucu nabi Muhammad Saw. Yang bernama Husain. ${ }^{6}$ Eksklusifnya posisi seorang Sayid di tengah masyarakat Hadrami sebagaimana yang ditulis Van den Berg, yaitu: Sayid di Hadramaut adalah wakil agama dan hukum. Mereka mengatur opini public dan masyarakat memberi perhatian yang sangat tinggi kepada mereka. Jika ada seorang Sayid yang masuk sebuah ruangan penuh orang, maka semua yang hadir harus mencium tangannya walaupun mereka sudah lebih tua atau lebih pintar. ${ }^{7}$

\section{Dasar lapisan masyarakat.}

Diantara lapisan atas dengan yang terendah, terdapat lapisan yang jumlahnya relative banyak. Biasanya lapisan atas, tidak hanya memiliki satu macam saja dari apa yang dihargai oleh masyarakat. Akan tetapi kedudukannya yang tinggi itu bersifat komulatif artinya mereka yang mempunyai uang banyak, akan mudah sekali mendapatkan tanah, kekuasaan dan mungkin juga kehormatan. Ukuran atau criteria yang biasa dipakai untuk mengolong-golongkan anggota masyarakat kedalam suatu lapisan adalah sebagai berikut :

${ }^{6}$ Bisri Affandi, MA, Syaikh Ahmad Syurkati (874-1943), Pembaharu dan Pemurnian Islam di Indonesia (cet.I; Jakarta: Al-Kautsar,1999), h. 62-63

${ }^{7}$ Ibid., h. 63 


\section{$\Delta L-n i s h \exists \bar{\Delta} H$,Vol. 11 No. 2, Juli-Desember 2015: 293-300}

a. Ukuran kekayaan. Barang siapa yang memiliki kekayaan paling banyak, termasuk lapisan teratas. Kekayaan tersebut dapat dilihat pada bentuk rumah yang bersangkutan, mobil pribadinya, caranya mempergunakan pakaian, bahan pakaian yang dipergunakannya, kebiasaan berbelanja, barang-barangnya mahal dan seterusnya.

b. Ukuran kekuasaan. Barang siapa yang memiliki kekuasaan atau yang memilki wewenang terbesar, menempati lapisan teratas.

c. Ukuran kehormatan. Ukuran kehormatan tersebut mungkin terlepas dari ukuran - ukuran kekayaan atau kekuasaan. Orang yang paling disegani dan dihormati, mendapat tempat yang teratas. Ukuran semacam ini, banyak dijumpai pada masyarakat tradisional. Biasanya mereka adalah golongan tua atau yang pernah berjasa.

d. Ukuran ilmu penegetahuan. Ilmu penegetahuan sebagai ukuran, dipakai oleh masyarakat yang menghargai ilmu pengetahuan. Akan tetapi ukuran tersebut kadang -kadang menyebabkan terjadinya akibat-akibat yang negative. Karena ternyata bahwa bukan mutu ilmu pengetahuan yang dijadikan ukuran, akan tetapi gelar keserjanaannya. Sudah tentu hal yang demikian memicu segala macam usaha untuk mendapat gelar, walau tidak halal. ${ }^{8}$

\section{Unsur - Unsur Lapisan Masyarakat}

Hal yang mewujudkan unsur dalam teori sosiologi tentang sistem lapisan masyarakat adalah kedudukan (status) dan peranan (role). Kedudukan dan peranan merupakan unsur-unsur baku dalam sistem lapisan, dan mempunyai arti yang sangat penting bagi sistem sosial. ${ }^{9}$ Ungkapan Selo Soemardjan dan Soemardi diatas, jika ditarik kedalam ruang lingkup masyarakat Islam sebagai tolak ukur dalam posisi sosiologi di masyarakat Islam, maka hal ini tidak bertentangan dengan kaedah dan norma-norma Islam itu sendiri. Di dalam Islam juga sering dibicarakan

\footnotetext{
${ }^{8}$ Soerjono Soekanto, Sosiologi..., h. 262-263

${ }^{9}$ Ibid. h. 264
} 
Syamsuriah Syamsuriah, STRATIFIKASI SOSIAL DALAM ISLAM: Tinjauan...

tentang status dan kedudukan, misalnya bagaimana sebenarnya posisi Nabi dan Rasul sehingga ada di muka bumi ini.

\section{B. Kriteria Agama}

Status sosial yang paling baik dan mulia, makhluk yang dinamakan Manusia adalah makhluk yang paling sempurna dibandingkan makhluk ciptaan Allah yang lainnya, karena manusia mempunyai status yang paling mulia dan terhormat di muka bumi ini dibandingkan dengan makhluk- makhluk yang lainnya, karena makhluk manusia telah diangkat oleh Allah sebagai khalifahnya di muka bumi ini. Ini berdasarkan firmannya dalam surah al-An'ām: 165 artinya : "Dan Dialah menjadikan kamu sebagai khalifah di muka bumi, dan Dia telah meninggikan sebagian kamu atas sebagian lainnya beberapa derajat, untuk menguji kamu tentang karuniaNya kepada kamu". ${ }^{10}$

Kata khalifah yang dimaksud dalam ayat tersebut berarti khalifah atau kepala Negara seperti zaman Abu Bakar Shiddiq, Umar bin Khattab, Usman bin Affan dan Ali bin Abu Thalib. Kata khalifah bisa juga berarti penguasa sebagai wakil Allah yang bertugas memakmurkan bumi ini, dan bisa juga berarti suatu generasi yang menggantikan generasi sebelumnya. ${ }^{11}$ Dari kata khalifah juga dapat ditarik suatu gambaran bahwa stratifikasi sosial dalam Islam sudah ada, misalnya bagaimana masyarakat Islam di Madinah yang dibangun oleh nabi Muhammad Saw. ${ }^{12}$ Dan pada ayat diatas juga disebutkan criteria-criteria orang-orang yang mulia di muka bumi ini, maka hal ini menggambarkan suatu staratifikasi sosial dalam Islam.

${ }^{10}$ Drs. Abu Bakar Muhammad, Pembinaan Manusia Dalam Islam (Cet I ; Surabaya: Al-Ikhlas,1994), h. 95

${ }^{11}$ Ibid.

${ }^{12}$ Akram Dhiyauddin Umari, Masyarakat Madani: Tinjauan Historis Kehidupan Zaman Nabi (cet II; Jakarta: Gema Insani Press,1999), h.77 


\section{$\Delta L-$ nis $H \exists \bar{\Delta} H$,Vol. 11 No. 2, Juli-Desember 2015: 293-300}

\section{Argumentasi Islam: Tingkah Laku Dan Perbedaan Sosial}

Sebagaimana dalam gambaran, Alqurān telah meletakkan batasbatas yang diberikan Allah SWT, dan telah memerintahkan semua anggota masyarakat Islam untuk memenuhi tuntutan-tuntutan serta batasbatas, perbuatannya harus dipertanggungjawabkan dihadapan Allah SWT, hal ini sebagaimana yang tercantum didalam Surah Hūd (11): $18^{13}$. Dengan demikian menyalurkan kehidupan manusia serta memberi disiplin. sekali lagi ia menekankan kegiatan-kegiatan yang ada tujuan dan hasilnya. Akan tetapi suatu kegiatan yang benar-benar bertujuan dan mendatangkan hasil tidaklah mungkin tanpa perencanaan yang matang, yang ada gilirannya menuntut adanya kedisiplinan. Lagi pula perinsip disiplin merupakan jiwa prilaku Islam. Dengan demikian masyarakat Islam adalah masyarakat berdisiplin. ${ }^{14}$

Alqurān menekankan persaudaraan orang-orang yang beriman bersama-sama semua implikasi, dengan demikian masyarakat Islam adalah masyarakat persaudaraan. ${ }^{15}$ Aturan-aturan yang sudah ditetapkan dalam Alqurān yang berhubungan dengan hubungan internasional di kalangan muslim dan non muslim serta etika Alqurān mengenai perang didasarkan atas keadilan mutlak serta mengakui kerendahan hati. Demikian pula, Alqurān melarang orang - orang Islam untuk memburu buru orang non muslim dan dipaksa masuk agama Islam, juga Alqurān menekankan bahwa Muslim harus absen untuk berbuat kebajikan bagi non-Muslim, kecuali kalau mereka tinggal di Negara yang aktif memusuhi mereka. Dengan demikian masyarakat Islam adalah Masyarakat Manusiawi. ${ }^{16}$

\footnotetext{
${ }^{13}$ Departemen Agama RI, Alquran..., h. 223

${ }^{14}$ Fazl-Ur-Rahman Ansari, Konsep..., .h. 172

${ }^{15}$ Ibid

${ }^{16}$ Ibid
} 
Syamsuriah Syamsuriah, STRATIFIKASI SOSIAL DALAM ISLAM: Tinjauan...

\section{Kesimpulan}

Pelapisan di dalam suatu keluarga atau masyarakat didasarkan atas nilai - nilai yang dimiliki oleh individu tersebut, jika di dalam suatu lingkungan keluarga memiliki nilai- nilai tinggi maka orang itu menempati posisi teratas di lingkungan keluarga tersebut.

Ukuran atau kriteria yang biasa dipakai untuk menggolonggolongkan anggota- anggota masyarakat Islam, yaitu Takwa, kekayaan, kekuasaan, kehormatan dan ilmu pengetahuan.

Bentuk - bentuk kongkrit lapisan masyarakat tersebut banyak. Akan tetapi secara prinsipil bentuk-bentuk tersebut diklasifikasikan kedalam tiga macam kelas, yaitu yang ekonomis, politis dan yang didasarkan pada jabatan- jabatan tertentu dalam masyarakat.

\section{Daftar Pustaka}

Affandi, Bisri, dan Syaikh Ahmad Syurkati (874-1943). Pembaharu dan Pemurnian Islam di Indonesia, Cet.I; Jakarta: Al-Kautsar, 1999.

Ali, Muhammad daud H. Pendidikan Agama Islam, Ed. I, Cet.II; Jakarta : PT. RajaGrafindo Persada, 1998.

Ansari, Muhammad Fasl-Ur-Rahman. Konsep Masyarakat Islam Modern, Cet.1; Bandung: Risalah Bandung, 1983.

Departemen Agama R.I, Alquran dan Terjemahannya, Semarang ; Toha Putra, 1998

Muhammad, Abu Bakar. Pembinaan Manusia Dalam Islam (Cet I; Surabaya: Al-Ikhlas, 1994

Soekanto, Soerjono. Sosiologi Suatu pengantar, Ed.IV, Cet. XXV ; Jakarta : PT. RajaGrafindo Persada, 1998.

Umari, Akram Dhiyauddin. Masyarakat Madani:Tinjauan Historis Kehidupan Zaman Nabi, Cet II; Jakarta: Gema Insani Press, 1999. 